\title{
Biological Nitrogen Fixation in the Context of Global Change
}

\author{
José Olivares, Eulogio J. Bedmar, and Juan Sanjuán \\ Dpto. Microbiología del Suelo y Sistemas Simbióticos, Estación Experimental del Zaidín, CSIC Prof. Albareda 1, E-18008 \\ Granada, Spain
}

Submitted 19 December 2012. Accepted 23 January 2013.

\begin{abstract}
The intensive application of fertilizers during agricultural practices has led to an unprecedented perturbation of the nitrogen cycle, illustrated by the growing accumulation of nitrates in soils and waters and of nitrogen oxides in the atmosphere. Besides increasing use efficiency of current $\mathbf{N}$ fertilizers, priority should be given to value the process of biological nitrogen fixation (BNF) through more sustainable technologies that reduce the undesired effects of chemical $\mathbf{N}$ fertilization of agricultural crops. Wider legume adoption, supported by coordinated legume breeding and inoculation programs are approaches at hand. Also available are biofertilizers based on microbes that help to reduce the needs of $\mathbf{N}$ fertilization in important crops like cereals. Engineering the capacity to fix nitrogen in cereals, either by themselves or in symbiosis with nitrogen-fixing microbes, are attractive future options that, nevertheless, require more intensive and internationally coordinated research efforts. Although nitrogen-fixing plants may be less productive, at some point, agriculture must significantly reduce the use of warming (chemically synthesized) $N$ and give priority to BNF if it is to sustain both food production and environmental health for a continuously growing human population.
\end{abstract}

Many human activities release greenhouse gases to the atmosphere. Although some people think that climate change is part of a natural process and that the idea of anthropogenic global warming is unfounded (Lindzen 2007), there is largely general agreement that $\mathrm{CO}_{2}$ levels have been sharply increasing since the beginning of the industrial era and will reach $450 \mathrm{ppm}$ within the next 50 years (IPCC 2007), with important environmental consequences. Transport and industry are considered the major sources of pollution and $\mathrm{CO}_{2}$, the principal cause, but there are other not so noticeable activities that play an important role in global warming. This is the case with agriculture and livestock farming, which contribute to climate change by releasing greenhouse gases with much greater globalwarming potential (GWP) than $\mathrm{CO}_{2}$, such as nitrous oxide derived mainly from organic and mineral nitrogen fertilizers and methane coming from livestock digestion processes and stored animal manures. Paradoxically, agriculture productivity is very sensitive to climate change (Adams et al. 1990; Hatfield et al.

Corresponding author: Juan Sanjuán; Telephone: +34-958-181600 Ext. 259; Fax: +34-958-129600; E-mail: Juan.Sanjuan@eez.csic.es

(C) 2013 The American Phytopathological Society
2011; Walther 2002). For instance, a small increase in air temperature might have a strong negative impact on crop production (Ortiz et al. 2008). This vicious circle can be broken through a series of actions, some of which are related to the nitrogen cycle.

Plant biomass and productivity of many ecosystems are limited by the availability of nitrogen (Elser et al. 2007). Although molecular nitrogen $\left(\mathrm{N}_{2}\right)$ is an unlimited resource, accounting for $78 \%$ of the atmospheric gases, this is not a form useful to plants. $\mathrm{N}_{2}$ must be chemically or biologically reduced (nitrogen fixation) into a plant-accessible form. The so-called green revolution increased crop yields, thanks to the use of improved plant varieties and the application of high doses of chemically synthesized nitrogen fertilizers. The world population could not have grown from 1.6 billion in 1900 to today's more than 6 billion without the synthesis of ammonia through the industrial Haber-Bosch process, which Smil (1999) considers the most important invention of the 20th century. Although nitrogen fertilization has diminished famine in many regions, this has been at an important environmental cost. The Haber-Bosch process involves the production of high quantities of $\mathrm{CO}_{2}$ (approximately 275 million tons per year) at the expense of fossil fuels such as natural gas and coal. The use efficiency of chemical fertilizers is very low, and most of the applied $\mathrm{N}$ fertilizer is socially a waste, since it is not consumed by humans (Robertson and Vitousek 2009). Furthermore, nitrogen is very mobile, and the applied $\mathrm{N}$ fertilizers pollute rivers and lakes and cause eutrophication of terrestrial and aquatic systems and increase global acidification and stratospheric ozone losses (Galloway et al. 2003), in addition to the greenhouse effects of the nitrous oxide released by the activity of denitrifying bacteria (discussed below).

\section{THE NITROGEN CYCLE AND CLIMATE CHANGE}

Authors, such as Elser (2011), have commented about the extent to which human activities have increased the available nitrogen with important consequences for all ecosystems. Indeed, Vitousek and associates (1997) reported that the rates of nitrogen inputs in the biosphere may have doubled since the preindustrial era. In the 1990s alone, more than $160 \mathrm{Tg}$ of nitrogen per year were introduced into the environment through fertilizer synthesis and nitrogen oxides derived from fossil-fuel burning (Galloway et al. 2004, 2008). The biogeochemical cycles of all elements are interconnected, so that the alteration of the nitrogen cycle by the antropogenic action cannot be considered separately from other elements, especially the carbon cycle (Fallowski 1997; Gruber and Galloway 2008). The 
increase of $\mathrm{CO}_{2}$ concentration in the atmosphere may have a positive effect on plant growth and water use efficiency (Ainsworth and Rogers 2007), although these positive impacts may be countered by heat stress (Hatfield et al. 2011). However, under not-too-extreme circumstances, this positive effect on plant growth would require additional applications of fertilizer, bringing into question whether sufficient nitrogen is available to allow the absorption of the excess $\mathrm{CO}_{2}$ in the earth's biosphere (Denman et al. 2007; Heimann and Reichstein 2008).

There are two biological processes within the nitrogen cycle, denitrification and nitrogen fixation, which have great but opposite implications for the climate change. The first one adds to the greenhouse effect by releasing $\mathrm{N}_{2} \mathrm{O}$ with a GWP of 310 , whereas the second can help to reduce undesirable effects of nitrogen fertilization. Although the human perturbation of the $\mathrm{N}$ cycle due to the increased production of $\mathrm{N}$ fertilizer and of oxidized reactive $\mathrm{N}$ compounds originating from fossil fuel combustion have led to an unprecedented accumulation of nitrogen oxides, mainly $\mathrm{N}_{2} \mathrm{O}$, in the biosphere (Erisman et al. 2009), evidence has accumulated to suggest that most $\mathrm{N}_{2} \mathrm{O}$ has its origin in microbial denitrification activity in soils and waters contaminated with nitrates. Denitrification is an alternative form of respiration in which bacteria sequentially reduce nitrate $\left(\mathrm{NO}_{3}{ }^{-}\right)$or nitrite $\left(\mathrm{NO}_{2}^{-}\right)$to dinitrogen $\left(\mathrm{N}_{2}\right)$ when oxygen concentrations are limited, according to the reaction: $\mathrm{NO}_{3}{ }^{-} \rightarrow \mathrm{NO}_{2}{ }^{-} \rightarrow$ NO (nitric oxide) $\rightarrow \mathrm{N}_{2} \mathrm{O}$ (nitrous oxide) $\rightarrow \mathrm{N}_{2}$. The enzymes involved in denitrification are nitrate, nitrite, nitric oxide, and nitrous oxide reductase, encoded by nar/nap, nir, nor, and nos genes, respectively (Richardson 2011; van Spanning et al. 2007). The switch from oxygen to nitrate respiration leads to a reduction in the adenosine triphosphate (ATP) yield rates but allows bacteria to survive and multiply (Zumft 1997). Although denitrification was believed to be performed exclusively by eubacteria, there is evidence that some fungi (Prendergast-Miller et al. 2011; Takaya et al. 2002), archaea (Treusch et al. 2005), and some Foraminifera and Gromiida (Piña-Ochoa et al. 2010) are also able to denitrify. Nitrifiers also have genes involved in denitrification (Cebron et al. 2005; Shaw et al. 2006).

It is notable that bacteria capable of achieving complete denitrification, that is the conversion of nitrate and nitrite to $\mathrm{N}_{2}$, are scarce. Most of them do not possess or do not express the complete set of enzymes required to carry out each one of the reduction steps that comprise denitrification. It is therefore a paradox that, being the only known biological process to remove excess nitrates that pollute soil and water ecosystems, denitrification is also a mechanism producing gaseous intermediate gases ( $\mathrm{NO}$ and $\mathrm{N}_{2} \mathrm{O}$ ) with an enormous impact on air pollution. Thus, excess nitrate affects not only terrestrial and marine ecosystems but, also, contributes to the release to the atmosphere of greenhouse gases involved in climate change (Sutton et al. 2011).

Assessment of denitrification by soils is not simple, due to the difficulties of quantifying its gaseous end products $\left(\mathrm{N}_{2} \mathrm{O}\right.$ and $\mathrm{N}_{2}$ ) and high spatial and temporal variability (Baggs and Philippot 2011; Groffman et al. 2006). Although molecular methods (Philippot and Hallin 2006) have contributed to a better knowledge of denitrification, methodological problems continue hampering our understanding of the process on site, from landscape to continental scale (Bru et al. 2011; Keil et al. 2011). Agricultural soils are the main anthropogenic source for atmospheric $\mathrm{N}_{2} \mathrm{O}$, contributing 5.3 to $6.8 \mathrm{Tg}$ of $\mathrm{N}_{2} \mathrm{O}-\mathrm{N}$ per year, which represents 40 to $60 \%$ of the total global atmospheric $\mathrm{N}_{2} \mathrm{O}$ source strength (Butterbach-Bahl and Dannenmann 2011, Shyakila and Kroeze 2011). Out of the $6.8 \mathrm{Tg}$ of $\mathrm{N}_{2} \mathrm{O}-\mathrm{N}$ per year, about $4.2 \mathrm{Tg}$ are due to direct emission of $\mathrm{N}$ added to the soil as fertilizer; indirectly, $2.1 \mathrm{Tg}$ of $\mathrm{N}_{2} \mathrm{O}-\mathrm{N}$ per year derive from dung and manure management and $0.5 \mathrm{Tg}$ of $\mathrm{N}_{2} \mathrm{O}-\mathrm{N}$ per year is formed during biomass burning (Baggs and Philippot 2011).

The 2011 Edinburg Declaration on Reactive Nitrogen recognized the negative impacts of reactive nitrogen on human health, climate and biodiversity, water, soil and air quality, as well as a variety of options to reduce polluting emissions from industry, transport, and agriculture, in this latter case, by improving nitrogen use efficiency (Gutierrez 2012). In this panorama, it is worth paying attention to the biological nitrogen fixation (BNF) which, contrary to the industrial process, has significantly lower economic and environmental costs. On a global scale, it represents the incorporation to the biosphere of some 110 and $140 \mathrm{Tg}$ per year on land or in the ocean, respectively (Galloway et al. 2004). BNF is a crucial process from the environmental and agricultural points of view, just second to photosynthesis in importance for the maintenance of the biosphere.

The ability to reduce inert atmospheric nitrogen to ammonia is restricted to some prokaryotes that are able to break the strong triple bond within the $\mathrm{N}_{2}$ molecule, with the key participation of the enzyme nitrogenase, to produce ammonium. The process requires high doses of energy and the nitrogenase is rapidly inactivated by oxygen. It was in 1888 that Hellriegel and Wilfarth uncovered the microbial origin of the root nodules of legumes, which Malpighi had already reported in 1679, which provide nitrogen to the host. In 1890, Beijerinck isolated the bacteria from nodules and named it Bacillus radicicola, which afterwards was generalized as Rhizobium and, today, includes diverse families of $\alpha$ - and $\beta$-proteobacteria. The Rhizobium-legume symbiosis is by far the most important and probably more efficient nitrogen-fixing system. The same author discovered the N-fixing ability in nonsymbiotic microorganisms such as members of genera Azotobacter and Clostridium. Since then, many genera of bacteria and archaea have been reported as either able to use molecular nitrogen as a nutrient or able to transfer the fixed ammonia to plants through the establishment of mutualistic symbioses. According to current data (Dos Santos et al. 2012), the distribution of nitrogen fixation and nitrogenase-like sequences among microbial genomes are much more common than previously thought.

Between the two extreme $\mathrm{N}_{2}$ fixers, pure diazotrophs and ammonium donors like rhizobia, are the so-called associative symbioses. Nitrogen fixation is a highly energy-demanding process and, therefore, free-living fixers have limited agronomic significance compared with plant-associated fixers, which can obtain their energy requirements from plant exudates. In associative symbioses, $\mathrm{N}_{2}$ fixers colonize plant surfaces and can even invade root intercellular spaces; however, no specialized $\mathrm{N}_{2}$-fixing structures are formed and ammonia cannot be directly transferred to the plant. Instead, some of these associative bacteria promote plant growth by other mechanisms (such as production of plant growth-regulating substances) not involving nitrogen fixation (Dobbelaere at al. 2003; Elmerich and Newton 2007; Spaepen et al. 2009). Franche and associates (2009) reviewed the nitrogen-fixing bacteria associated with leguminous and nonleguminous plants.

Among free-living fixers are cyanobacteria, which combine oxygenic photosynthesis with nitrogen fixation and have developed different strategies to make compatible both processes, considering that nitrogenase is inactivated by oxygen. In some cases cyanobacteria (Anabaena and Nostoc spp.) associate with plants such as terrestrial nonvascular bryophytes, aquatic ferns (Azollaceae), certain gymnosperms (Cycads), and angiosperms (Gunnera) and are able to transfer directly the fixed ammonia to the host plant. Nostoc spp. can also associate with fungi (lichens) and even with plant symbiotic mycorrhizal fungi (Geosiphon) (Meeks 1998, 2009). 
BNF FOR MORE SUSTAINABLE FOOD PRODUCTION AND ENVIRONMENTAL HEALTH

The quantity of nitrogen needed for agriculture is projected to increase in the next decades, which could lead to greater environmental pollution. Lesser dependence on fertilizer $\mathrm{N}$ and more attention to practices that favor BNF in farming systems will benefit both agriculture and the environment. Considering the potential of BNF to reduce the excess application of chemically fixed nitrogen and its impact on the environment, a number of actions should be considered to improve exploitation of this biological process: i) the optimal use of known nitrogen-fixing systems; ii) development of new fixing plantmicrobe associations; and iii). transfer of the nitrogen-fixing ability to nonfixing organisms.

\section{Optimal use of known $\mathbf{N}_{\mathbf{2}}$-fixing systems.}

Symbiotic nitrogen fixation by legumes. There are a number of approaches to improve BNF by legumes, such as wider legume adoption, plant breeding and selection, and inoculant usage. The adoption of legumes in farming systems must be a thoughtful decision that should evaluate the actual needs and social demands as well as the biotic and abiotic interactions that may limit crop productivity. In addition, it should consider not only profitability but, also, the greater environmental sustainability that legume nitrogen fixation provides, especially in intercropping and crop rotations (Sessitsch et al. 2002). Moreover, since nitrogen-fixing plants have substantially lower requirements of $\mathrm{N}$ fertilization and, therefore, consume less fossil energy, the use of legumes for feedstock provision to biorefineries should be considered (Jensen et al. 2012).

Nodulation with the best nitrogen-fixer rhizobia must be assessed to maximize BNF by legumes. Thus, in soils devoid of or with low numbers of the compatible rhizobia, inoculation with elite strains is a must. Considerations in the selection of an inoculant strain must include not only bacterial compatibility and high nitrogen-fixing efficiency with the available legume genotypes but also its adaptation to the prevalent soil and environmental conditions in each region, particularly when one or several abiotic constraints (such as drought, acidity, and others) may limit the symbiotic activity and survival of the inoculant. In addition, the need of periodical reinoculation must also be assessed, as this practice may ensure highest productivities (Hungria et al. 2005)

The situation becomes much more complex when high numbers of nodulating rhizobia exist in soil. In these cases, it must be assessed whether the selected legume genotype can effectively nodulate with the native populations. In case the native rhizobia are poor nitrogen fixers, probably two nottrivial actions must be taken, i.e., select legume genotypes that show no interaction with the soil rhizobia (to take advantage of the so-called genotype-specific nodulation) and select an effective and competitive inoculant. In soils with high rhizobial numbers, competition for nodulation becomes a key aspect of inoculant success. Soil rhizobia compete with the inoculant for nodule occupancy, thereby reducing the success of the latter and decreasing nitrogen fixation rates and plant productivity when the soil competitors are poor fixers. Rhizobial competitiveness is a very complex feature that involves multiple capacities, such as metabolic competence (both to utilize metabolites and to resist antimetabolites released with root exudates [Cai et al. 2009; Wielbo et al. 2007]), motility, tolerance to biotic and abiotic factors, ability to overcome plant defenses, and more. Rhizobial competitiveness can also be modulated by specific soil management practices and through inoculant formulation and application (Sessitsch et al. 2002).
Inoculant selection is usually derived from the screening of the existing rhizobial diversity, particularly in soils in which the legume has been cultivated previously or in centers of origin or diversification of the legume. However, there are a number of genetic modifications that have been shown to enhance the symbiotic efficiency of a given strain. For instance, the liberation of $\mathrm{H}_{2}$ concomitant to reduction of nitrogen by nitrogenase is a source of intrinsic inefficiency of the BNF process. Some rhizobial strains harbor a hydrogen uptake system that catalyzes the oxidation of $\mathrm{H}_{2}$ evolved by nitrogenase, thereby recovering part of the wasted energy. This character can be transferred to rhizobial strains unable to recycle $\mathrm{H}_{2}$ (Bascones et al. 2000; Ureta et al. 2005). Reiteration or overexpression of genes important for nitrogenase activity is another approach to enhance efficiency. For instance, Peralta and associates (2004) found that strains of Rhizobium etli lacking poly- $\beta$-hydroxibutyrate and overexpressing nitrogenase increased nitrogenase activity, plant weight and seed yield of Phaseolus vulgaris. Rhizobium inoculant strains carrying this type of modification are currently commercialized in Mexico. Likewise, enhanced expression of genes for the $c b b 3$ terminal oxidase, dedicated to energy production in bacteroids, enhances symbiotic efficiency and tolerance to drought (Talbi et al. 2012). Bosworth and associates (1994) reported that the overexpression of the regulatory nitrogen fixation gene (nifA) and C4-dicarboxylic acid transporter (dctA) in Sinorhizobium meliloti enhances the productivity of alfalfa under nitrogenlimiting conditions.

Inoculant selection must be viewed as a continued task that needs to keep pace with legume improvement to always maintain the highest levels of nitrogen fixation. As new cultivars are developed or soil and environmental conditions change, new inoculant needs will arise.

Virtually all agriculturally important legumes can fix nitrogen in symbiosis with their rhizobial counterparts. However, the contribution of BNF to legume production may have declined over the years, owing to a number of factors, such as the availability of $\mathrm{N}$ fertilizers (particularly for farmers in developed countries), edaphic and environmental constraints, or the use of legume varieties with limited ability to fix $\mathrm{N}_{2}$ (Graham et al. 2004). There are evidences of losses of BNF capacity in modern cultivars (Bohrer and Hungria 1998; van Kessel and Hartley 2000). The current trend of producing new high-yielding cultivars and new intensive crop management practices result in even higher plant demands for nitrogen. This creates a conflicting situation with higher yielding and $\mathrm{N}$-demanding cultivars but lower nitrogen fixation capacity, which is usually balanced with the nonsustainable solution of higher applications of fertilizer $\mathrm{N}$. Nodulation and $\mathrm{N}_{2}$ fixation in legumes are considered quantitative traits and quantitative trait loci (QTL) have been identified in some cases (Nicolás et al. 2006). Considerable variability in nodulation and nitrogenfixation capacity has been found among commercial cultivars, therefore there exist contrasting materials to be used as sources of nodulation QTL (Salvucci et al. 2012). The venue of the complete genome sequences of several crop and model legumes (Medicago and Lotus spp., soybean, common bean), together with the wide array of available genetic resources should lead to better understanding of the physiology of legumes but also to facilitating future marker-assisted breeding for enhanced nitrogen fixation (Schauser et al. 2008).

A number of strategies for enhancing legume nitrogen fixation through breeding have been suggested, such as maximizing plant biomass and seed yield within the constraints imposed by agronomic management and the environment, to enhance the ability of the legume to nodulate and fix nitrogen in the presence of soil nitrate, and optimizing nodulation 
through specific nodulation traits, including the continuous matching of plant and rhizobial genotypes, particularly for specific environmental niches (Herridge and Rose 2000). Breeding for enhanced nitrogen fixation may appear to be not an easy task, however, there are parameters such as seed yield and plant biomass $\mathrm{N}$ or nodule mass per plant that are easy to measure and are directly related to fixing efficiency. Moreover, there is the view that just breeding for high yield could itself enhance $\mathrm{N}_{2}$ fixation, provided that breeders carry out their selections in soils with low $\mathrm{N}$ content, in which the plant is forced to fix nitrogen in symbiosis with either the native rhizobial populations or, much better, with a rhizobial inoculant strain that has demonstrated high $\mathrm{N}_{2}$-fixing efficiency (Graham et al. 2004). Likewise, breeding for tolerance to abiotic stresses like drought, temperature, salinity, acidity, and more should always consider the need to count on highly efficient rhizobial strains that are, themselves, well adapted to the prevalent constrains. Plant breeding programs and associated rhizobial selection that consider the importance of BNF for legume productivity and agrosystem sustainability should be implemented not only for globally important crops like soybeans but especially for legume cultures of local and regional importance. In this sense, it is necessary to mention initiatives like the N2Africa program, aimed to put nitrogen fixation by legumes to work for smallholder farmers in Africa.

Free-living and associative nitrogen fixers. Although freeliving $\mathrm{N}_{2}$ fixers globally contribute to the incorporation of an important amount of nitrogen to the biosphere, their agricultural significance is, as mentioned above, too low. The reason is the shortage of glucose equivalents in the soil to cover the high energy requirements of nitrogenase, which adds to the costs of protecting the enzyme from oxygen, as in aerobic bacteria. The ammonia fixed, on the other hand, is not directly transferred from bacteria to plants. Many attempts have been made to use free-living fixers as biofertilizers. Already in the first half of the 20th century, inoculants based on Azotobacter spp. were commercialized (e.g., Azotobacterin, especially in Russia) with little success. Currently some Azotobacter inoculants are indicated to reduce $\mathrm{N}$ fertilizer application (i.e., Dimargon, Colombia, recommended for rice). However, the mechanism involved in crop improvement is unclear. Although Azotobacter paspali was earlier reported as a nitrogen-fixing bacteria associated to particular cultivars of Paspalum notatum (Döbereiner 1966; Döbereiner et al. 1972), other reports indicated that its plant growth-promoting abilities may be related to the production of phytohormones (Barea and Brown 1974). Indeed, the exploitation of nitrogen fixers that associate with plants without forming special structures, associative symbioses, seems more realistic. A number of commercial products based on plant growth-promoting rhizobacteria, particularly Azospirillum spp., which are also nitrogen fixers, are available worldwide. Most these microbes exhibit several mechanisms in addition to BNF that globally contribute to improve growth and mineral nutrition of the plant (e.g., phytohormone production, $\mathrm{P}$ solubilization). It is widely demonstrated that Azospirillum inoculation significantly reduces the needs of $\mathrm{N}$ fertilizer applied to different crops, particularly cereals (Dobbelaere et al. 2001). However, it is still controversial whether atmospheric nitrogen fixed by these bacteria is significantly incorporated by the host. While older studies indicated that the contribution of nitrogen fixation by Azospirillum spp. to the plant was minimal or null, more recent experiments suggest that atmospheric $\mathrm{N}$ fixed by the bacteria may represent a very significant portion of the total plant nitrogen content, the amounts varying upon specific bacteria-cultivar interactions (Bashan and Bashan 2010). Since N fixed by Azospirillum spp. is not directly available to the plant, a way of enhancing the amount of atmospheric nitrogen available to the host is through the exploitation of Azospirillum mutants that excrete the fixed ammonia. A glutamine synthetase (GS) (the first enzyme involved in assimilation of the fixed ammonium) point mutant displays an ammonium-excreting phenotype and performed better than the wild type for growth promotion of wheat (Van Dommelen et al. 2009). Moreover, strains combining mutations leading to both ammonium excretion and lack of flocculation further enhanced plant performance under N-limiting conditions (Kennedy et al. 2000). These results, at the same time, show the importance of contribution of nitrogen fixation by these plant-associated bacteria.

Closely related to the ammonia-excreting phenotype of Azospirillum mutants is the natural ammonium donation to the host by symbiotic nitrogen-fixing filamentous cyanobacteria like Nostoc or Anabaena spp. Although they can fix nitrogen in the free-living state, these cyanobacteria display greater rates of nitrogen fixation when associated to the host. When combined nitrogen is limiting, some vegetative cells differentiate into the so-called heterocysts, specialized for BNF. These cells have a less permeable wall for oxygen and lack oxygenic photosynthesis. Heterocysts constitute 5 to $10 \%$ of the total cells in free-living conditions, but their numbers increase several fold in symbiosis, perhaps as a response to signals produced by the plant partner (Meeks and Elhai 2002). In this state, more nitrogen than that required by the microsymbiont is reduced, causing the release of the excess ammonium, which can be used by the plant. GS activity is significantly lower in symbiotic than free-living $\mathrm{N}_{2}$-fixing cyanobacteria, which could explain the ammonia-excreting behavior. There is yet much to be learned about the mechanism involved in the transformation of cyanobacteria from an ammonium assimilator to an exporter. One or more plant signals that cause this change in GS activity or the increase in the number of heterocyts are unknown (Meeks 2009). Discovering this putative plant signals could help to manipulate free-living cyanobacteria to display high heterocyst numbers and low GS activity in the absence of the host (which would lead to ammonium export), could be used to produce either industrial "green manures," an industrial but biologically fixed ammonia, or both. In addition, better exploitation of Azolla green manures, which traditionally have sustained rice cultivation in many areas of Asia but have been substituted by application of $\mathrm{N}$ fertilizers, should be implemented (Ladha and Reddy 2000).

Diazotrophic endophytes. Certain nonlegume crops, such as sugarcane and rice, can directly benefit from BNF through association with bacterial diazotrophs that are able to infect, multiply, and spread inside the roots and aerial parts of the plants without causing a health damage or ecological threat to their hosts. Several of these diazotrophic endophytes (e.g., Gluconacetobacter diazotrophicus, Herbaspirillum, Burkholderia, and Azoarcus spp.) have been characterized and, in some cases, nitrogen fixation inside the host and plant gains of atmosphere-derived nitrogen have been demonstrated (Boddey et al. 2003; Hurek and Reinhold-Hurek 2003). Although progress has been made on the understanding of this type of beneficial plant-microbe interaction, the contribution of single species to the host nitrogen balance is still unclear. The measured gains of nitrogen in the field cannot be explained by the modest to moderate contribution of the diazotrophic endophytes in gnotobiotic systems. As an example of this complexity, Burbano and associates (2011) unexpectedly recently found the prevalence of a particular nitrogenase phylotype inside roots but not the stems of sugarcane and Norway spruce.

It seems likely that the historically sustained long-term cultivation of sugarcane or rice without significant additions of $\mathrm{N}$ fertilizer may benefit from complex endophytic and rhizospheric 
microbial consortia. Under this premise, complex inoculants are being developed for sugarcane in Brazil (Silva et al. 2012). Likewise, the successful field performance of several combinations of rice endophytes has been reported (Yanni and Dazzo 2010). As for other examples of plant-growth promotion by microorganisms, it is possible that the synergic activities of several microbes and growth-promoting mechanisms, besides nitrogen fixation, are responsible for the beneficial effects observed with endophytic diazotrophs. In addition, a poorly understood interaction between plant genotype and soil and environmental conditions seem to determine the contribution of endophytic BNF to plant productivity (Oliveira et al. 2006). Therefore, more knowledge is needed to fully understand BNF in these important crops and to extend their benefits to other agriculturally important (e.g., graminaceous) species.

Actinorhizal nitrogen-fixing symbioses. Actinomycete Frankia spp. establish a nitrogen-fixing symbiosis with at least eight dicotiledoneus plant families and 25 genera (Benson and Silvester 1993). There are approximately 200 actinorhizal woody plant species, in which the specificity of the association, in contrast to the Rhizobium-legume symbiosis, is rather low. This gives the actinorhizal symbiosis a special interest in relation to the potential extension of the nitrogen-fixing ability to other systems. The lack of exhaustive genetic information on both bacteria and plant partners hinders the study and understanding of these systems. Signal exchange during the early stages of the actinorhizal symbiosis is still poorly understood, although the identification of flavonoids as plant-signaling compounds and the role for auxins during Frankia infection and nodule organogenesis have been reported (Auguy et al. 2011; Perrine-Walker et al. 2010). Flavonoids could be the plant signal molecules that induce the synthesis by Frankia spp. of a symbiotic factor whose nature remains unknown, although some biochemical similarities to the rhizobial Nod factors have been suggested, in spite of the absence of nod-like genes in the Frankia genomes published so far (Ceremonie et al. 1999). The recognition of Frankia factor by yet-unknown plant-cell receptors might induce signaling cascades similar to those identified for the rhizobial and mycorrhizal symbioses (Hocher et al. 2011).

\section{Development of novel $\mathbf{N}_{\mathbf{2}}$-fixing symbioses.}

An attractive possibility to extend nitrogen fixation ability to originally nonfixing plants could be the exploitation of the Rhizobium-legume and the actinorhizal systems, using them as models to obtain novel plant-microbe nitrogen-fixing symbioses. In the two above systems, bacteria fix nitrogen inside root nodules in which low oxygen and abundant carbon sources are provided. Several aspects must be taken into consideration to develop novel types of bacteria-plant symbioses, such as signal exchange and recognition by the symbionts, the control of the plant defense responses, nodule organogenesis, and efficient $\mathrm{N}_{2}$ fixation and ammonium assimilation. Much information now exists about these aspects in the rhizobia-legume symbiosis (unfortunately the knowledge on the actinorhiza lags far behind) that could be used in future engineering of novel plant-microbe symbioses. The task can be greatly facilitated by the fact that many essential steps in the Rhizobium-legume symbiosis are shared with the universal arbuscular mycorrhizal symbiosis (Charpentier and Oldroyd 2010), from early plantmicrobe recognition and host signal transduction to the exocytotic pathways required for the formation of symbiosomes and arbuscules (the intracellular membrane compartments that host the microbes in each case) essential for plant-microbe nutrient exchange (Ivanov et al. 2012). Thus, many of the legume functions needed for nodule formation and hosting the rhizobial microsymbiont are likely present in most plants. It will be nec- essary to identify and decipher how those functions are regulated in legumes to be manipulated in others like cereals to be able to form readily infected and functional nodule-like structures. The characterization of the ancient and likely more simple process of nodulation in certain legumes like Aeschynomene spp. should be of great help to the goal of novel nitrogenfixing symbioses (Bonaldi et al. 2011). In addition, the control of plant defenses during symbiotic establishment will be a critical point, since a fine equilibrium might determine recognition of microbes as symbiotic or pathogenic by the host plants (Soto et al. 2009; Zamioudis and Pieterse 2012). A nearly $\$ 10$ million program has been recently funded to engineer cereals for symbiotic nitrogen fixation (John Innes Center News website).

There have been numerous reports since the 1990s about the formation of root outgrows or tumors, so-called paranodules, in graminaceous species, such as rice or wheat, and their invasion by diverse nitrogen fixers, such as azospirilla (Zeman et al. 1992), rhizobia (Christiansen-Weniger 1996), cyanobacteria (Gantar and Elhai 1999), or enterobacteria (Iniguez et al., 2004). Since studies by Ridge and coworkers (1992, 1993), many other researchers have found that nodule-like structures are formed on rice and wheat roots upon the application of auxins, 2,4-D, or indoleacetic acid. Bacteria invade these paranodules through cracks and establish intercellularly and, sometimes, also intracellularly. Invasion of paranodules by diazotrophic bacteria seem to favor nitrogen fixation when compared with the absence of outgrows (Christiansen-Weniger 1998). In spite of these promising results, there is yet much to be done to improve the limited nitrogenase activity and beneficial effects on plant nitrogen nutrition observed in these experimental systems. Among some clues are the limited number and the size of paranodules, which appear after phytohormone applications but do not continue to grow over the plant growth period (Biabani et al. 2012).

\section{Transfer of $\mathbf{N}_{\mathbf{2}}$-fixing capacity to other organisms.}

Another attractive action to be considered is the transfer of the $\mathrm{N}_{2}$-fixing ability to organisms initially unable to reduce $\mathrm{N}_{2}$. Among the possible recipients are prokaryotic and eukaryotic microorganisms as well as plants.

Transfer of nif genes from one species to another has no particular difficulty, it happens in nature (through lateral genetransfer processes), and it has been done in the laboratory since the beginning of the genetics of BNF (Dixon and Postgate 1972). Most free-living fixers reduce $N_{2}$ in anaerobiosis or microaerobisis, but these organisms are rather inefficient, owing to the high energy demands of the process (16 ATP per molecule of $\mathrm{N}_{2}$ reduced). Obligate aerobes, in addition, need to protect nitrogenase from oxygen inactivation, for which they have developed different strategies. In some cases, cells are surrounded with a thick mucilaginous layer that hinders oxygen diffusion; others like Azotobacter spp. or Gluconacetobacter diazotrophicus, display high respiration rates to soak the free oxygen, in addition to a conformational protection of nitrogenase under high oxygen levels (Poole and Hill 1997; Ureta and Nordlung 2002). BNF by these bacteria, however, is not very energetically efficient. For instance, Azotobacter spp. require more than $100 \mathrm{~g}$ of $\mathrm{C}$ per gram of $\mathrm{N}$ reduced, in contrast with the approximately $12 \mathrm{~g}$ of $\mathrm{C}$ consumed by rhizobia inside nodules, where bacteria are protected from high oxygen concentrations (Phillips 1980). Protection of nitrogenase and high energy efficiency would be the main two limiting factors for an industrial approach to BNF in which, as mentioned above, a $\mathrm{N}_{2}$-fixing and ammonium exporter organism, i.e., a cyanobacterium, could be used to replace the Haber-Bosch process. 
Some eukaryotic microorganisms could also be considered as potential receptors of nif genes to become nitrogen fixers. Arbuscular mycorrhizal (AM) fungi forming mutualistic symbioses with most land plants might be good candidates. These fungi, belonging to the phylum Glomeromycota, colonize biotrophically the root cortex and play a key role in plant nutrition. Present in almost all habitats and climates and essential in unfertile soils, AM fungi improve the acquisition of low mobility nutrients in the soil, especially phosphate and water, and increase the biotic and abiotic stress resistance of their host plants. In return, and similar to the Rhizobium-legume symbiosis, the plant provides the fungus with photoassimilates. The establishment of AM interactions and, in particular, fungus recognition by the host plant are mediated by a signaling pathway partly shared with the Rhizobium-legume symbiosis (Maillet et al. 2011). Unfortunately, the current inability to obtain pure cultures of these fungi or their stable genetic transformation needs to be solved before the possibility of a nitrogen-fixing mycorrizal fungus could be attempted.

The feasibility of having plants fixing their own nitrogen has been a long-debated issue (Merrick and Dixon 1984; Postgate 1974; Shanmugam and Valentine 1975). Engineering plants for nitrogen fixation is a very complex task that is far from being achieved; however, it is not as utopic as it appeared a few decades ago. With current and the yet-to-come knowledge and technology, the introduction of nif genes into a plant genome would be relatively simple compared with the complexity of achieving nitrogenase activity or efficient nitrogen fixation (Dixon et al. 1997). Among the three possible compartments of the complex plant genome to introduce the nif genes, the nucleus, the mitochondrion, or the chloroplast, the last two organelles could sustain nitrogenase function with the required quantity of ATP and reducing power. Dixon and coauthors (1997) proposed the chloroplast as the most appropriate organelle for expression of nif genes and discussed a number of technical, genetic, and physiological constraints that would be encountered along the way. The use of model plants such as unicellular algae may certainly facilitate the task before it can be tested in plants of agricultural importance. The necessary technology to transform plastids has been developed for tobacco and other plant species and the prokaryotic nature of transcription and translation in these organelles could facilitate the expression of the number (around 15) of nif genes required to produce active nitrogenase. This number could be reduced; in fact, only three genes are necessary for the in vitro synthesis of the iron molybdenum nitrogenase cofactor (FeMo-co) (Rubio and Ludden 2008). But nitrogen fixation is a very complex process that must be subject to strict regulation, with a high energetic dependency and requiring an anoxic environment. The energy could be well supplied in chloroplasts but in an oxygenated environment. This obstacle could be solved by temporal (dark versus light) or spatial separation from photosynthesis (i.e., root amyloplasts). The existence in many photosynthetic species of a light-independent and oxygen-sensitive nitrogenase-related metalloenzyme required for chlorophyll biosynthesis opens new expectations, since characterization of the features that allow this type of enzyme to function in chloroplasts could be applied to alleviate nitrogenase inactivation by oxygen (Yamamoto et al. 2011). The introduction and successful expression of the Fe-protein (nifH) gene in chloroplasts of Chlamydomonas reinhardtii has been achieved (Cheng et al. 2005). This gives renewed hope for the introduction of the complete set of genes needed to produce an active nitrogenase. However, sustained funding and more intensive and coordinated scientific efforts are required to face and overcome the obstacles blocking the way to attaining nitrogen-fixing plants (Dixon et al. 1997).

\section{PERSPECTIVES}

It is widely accepted that application of $\mathrm{N}$ fertilizers has decisively contributed to match the pace of food production with human population growth in the last decades. But there is also a consensus that this has been at a high environmental cost that is no longer sustainable. Besides a better use efficiency for current $\mathrm{N}$ fertilizers, the biological process of nitrogen fixation must be better exploited as a more sustainable technology to reduce the undesired effects of $\mathrm{N}$ fertilization of agricultural crops. Wider legume adoption, supported by coordinated legume breeding and inoculation programs are approaches at hand, as are biofertilizers based on microbials (mainly rhizospheric and endophytic bacteria) that help to reduce the needs of $\mathrm{N}$ fertilization in important crops such as cereals. Engineering in cereals the capacity to fix nitrogen, either by themselves or in symbiosis with nitrogen-fixing microbes, are attractive future options that nevertheless require more intensive and internationally coordinated research efforts. Since $\mathrm{N}_{2}$ fixation is more energy-demanding than the more simple nitrate or ammonium assimilation (Ryle et al. 1979), nitrogen-fixing plants may be less productive. This handicap may be neutralized by enhancing photosynthetic efficiency and applying crop management practices to allow optimal use of soil resources. However, at some point, agriculture must significantly reduce the use of warming (chemically synthesized) $\mathrm{N}$ and give priority to BNF, if it is to sustain both food production and environmental health for a continuously growing human population.

\section{ACKNOWLEDGMENTS}

We thank the Spanish government (Dirección General de Proyectos de Investigación) and the Junta de Andalucía (Plan Andaluz de Investigación) for continuous support by their I+D programs, in combination with Social European Funds.

\section{LITERATURE CITED}

Adams, R. M., Rosenzweig, C., Peart, R. M., Richie, J. T., McCarl, B. A., Glyer, J. D., Curry, R. B., Jones, J. W., Boote, K. J., and Allen, L. H., Jr., 1990. Global climate change and US agriculture. Nature 345:219224.

Ainsworth, E. A., and Rogers, A. 2007. The response of photosynthesis and stomatal conductance to rising $\mathrm{CO}_{2}$ : Mechanisms and environmental interactions. Plant Cell Environ. 30:258-270.

Auguy, F., Abdel-Lateif, K., Doumas, P., Badin, P., Guerin, P., Bogusz, D., and Hocher, V. 2011. Isoflavonoids pathway activation in actinorhizal symbioses. Funct .Plant Biol. 38:690-696.

Baggs, E. M., and Philippot, L. 2011. Nitrous oxide production in the terrestrial environment. Pages 23-37 in: Nitrogen Cycling in Bacteria: Molecular Analysis. J. W. B Moir, ed. Caister Academic Press, Norfolk, U.K.

Barea, J. M., and Brown, M. E. 1974. Effect on plant growth produced by Azotobacter paspali related to synthesis of plant growth regulating substances. J. Appl. Bacteriol. 37:583-393.

Bascones, E., Imperial, J., Ruiz-Argueso, T., and Palacios, J. M. 2000. Generation of new hydrogen-recycling Rhizobiaceae strains by introduction of a novel hup minitransposon. Appl. Environ. Microbiol. 66:4292-4299.

Bashan, Y., and Bashan, L. E. 2010. How the plant growth-promoting bacterium Azospirillum promotes plant growth-A critical assessment. Adv. Agron. 108:77-136.

Benson, D. R,, Silvester, W. B. 1993. Biology of Frankia strains, actinomycete symbionts of actinorhizal plants. Microbiol. Rev. 57:293-319.

Biabani A., Boggs, L. C., Natasha, K., and Morad, U. 2012. Microscopic morphology of nitrogen fixing paranodules on wheat roots. African J. Biotechnol. 11:2971-2976.

Boddey, R. M., Urquiaga, S., Alves, B. J. R., and Reis, V. 2003. Endophytic nitrogen fixation in sugarcane: Present knowledge and future applications. Plant Soil 252:139-149.

Bohrer, T. R. J., and Hungria, M. 1998. Availacao de cultivares de soja quanto a fixacao biologico do nitrogeno. Pesq. Agrop. Bras. 33:937953. 
Bonaldi, K., Gargani, D., Prin, Y., Fardoux, J., Gully, D., Nouwen, N., Goormatchtig, S., and Giraud, E. 2011. Nodulation of Aeschynomene afraspera and A. indica by photosynthetic Bradyrhizobium sp. strain ORS285: The nod-dependent versus the nod-independent symbiotic interaction. Mol. Plant-Microbe Interact. 24:1359-1371.

Bosworth, A. H., Williams, M. K., Albrecht, K. A., Kwiatkowski, R., Beynon, J., Hankinson, T. R., Ronson, C. W., Cannon, F., Wacek, T. J., and Triplett, E. W. 1994. Alfalfa yield response to inoculation with recombinant strains of Rhizobium meliloti with an extra copy of dctABC and/or modified nifA expression. Appl. Environ. Microbiol. 60:38153832

Bru, D., Ramette, A., Saby, N. P. A., Dequiedt, S., Ranjard, L., Joliver, C., Arrouays, D., and Philippot, L. 2011. Determinants of the distribution of nitrogen cycling microbial communities at the landscape scale. Int. Soc. Mol. Ecol. J. 5:532-542.

Burbano, C. S., Liu, Y., Rösner, K. M., Reis, V. M., Caballero-Mellado, J., Reinhold-Hurek, B., and Hurek, T. 2011. Predominant nifH transcript phylotypes related to Rhizobium rosettiformans in field-grown sugarcane plants and in Norway spruce. Environ. Microbiol. Reports. 3:383389.

Butterbach-Bahl, K., and Dannenmann, M. 2011. Denitrification and associated soil $\mathrm{N}_{2} \mathrm{O}$ emissions due to agricultural activities in a changing climate. Curr. Opin. Environ. Sust. 3:389-395.

Cai, T., Cai, W., Zhang, J., Zheng, H., Tsou, A. M., Xiao, L., Zhong, Z., Zhu, J. 2009. Host legume-exuded antimetabolites optimize the symbiotic rhizosphere. Mol. Microbiol. 73:507-517.

Cebron, A. and J. Garnier. 2005. Nitrobacter and Nitrospira genera as representatives of nitrite-oxidizing bacteria: Detection, quantification and growth along the lower Seine River (France). Water Res. 39:4979-4992.

Ceremonie, H., Debelle, F., and Fernandez, M. P. 1999. Structural and functional comparison of Frankia root hair deforming factor and rhizobia Nod factor. Can. J. Bot. 77:1293-1301.

Charpentier, M., and Oldroyd, G. 2010. How close are we to nitrogen-fixing cereals? Curr. Opin. Plant Biol. 13:556-564.

Cheng, Q., Day, A., Dowson-Day, M., Shen, G.-F., and Dixon, R. 2005. The Klebsiella pneumonia nitrogenase Fe protein gene (nifH) functionally substitutes for the chlL gene in Chamydomonas reinhardii. Biochem. Biophys. Res. Comm. 329:966-975.

Christiansen-Weniger, C. 1996. Endophytic establishment of Azorhizobium caulinodans through auxin-induced root tumors on rice (Oryza sativa L.). Biol. Fertil. Soils 21:293-302.

Christiansen-Weniger, C. 1998. Endophytic establishment of diazotrophic bacteria in auxin-induced tumors of cereal crops. Crit. Rev. Plant Sci. 17:55-76.

Denman, K. L., Brasseur, G., Chidthaisong, A., Ciais, P., Cox, P. M., Dickinson, R. E., Hauglustaine, D., Heinze, C., Holland, E., Jacob, D., Lohmann, U., Ramachandran, S., da Silva Dias, P. L., Wofsy S. C., and Zhang, X. 2007. Couplings between changes in the climate system and biogeochemistry. In: Climate Change 2007: The Physical Science Basis. Contribution of Working Group I to the Fourth Assessment Report of the Intergovernmental Panel on Climate Change. S. Solomon, D. Qin, M. Manning, Z. Chen, M. Marquis, K. B. Averyt, M. Tignor and H. L. Miller, eds. Cambridge University Press, Cambridge, U.K.

Dixon, R. A, and Postgate, J. R. 1972. Genetic transfer of nitrogen fixation from Klebsiella pneumoniae to Escherichia coli. Nature 237:102-103.

Dixon, R., Cheng, Q., Shen, G.-F., Day, A., and Dowson-Day, M. 1997. Nif gene transfer and expression in chloroplasts: Prospects and problems. Plant Soil 194:193-203.

Dobbelaere, S., Croonenborghs, A., Amber, T., Ptacek, D., Vanderleyden, J., Dutto, P., Labandera-Gonzalez, C., Caballero-Mellado, J., Aguirre, J. F., Kapulnik, Y., Shimon, B., Burdman, S., Kadouri, D., Sarig, S., and Okon, Y. 2001. Responses of agronomically important crops to inoculation with Azospirillum. Aust. J. Plant Physiol. 28:871-879.

Döbereiner, J. 1966. Azotobacter paspali sp. Nov., uma bacteria fixadora de nitrogenio na rhizosfera de Paspalum. Pesq. Agropec. Bras. 1:357365

Döbereiner, J., Day, J. M., and Dart, P. J. 1972. Nitrogenase activity and oxygen sensitivity of the Paspalum notatum-Azotobacter paspali association. J. Gen. Microbiol. 71:103-116.

Dobbelaere, S., Vanderleyden, J., and Okon, Y. 2003. Plant growth-promoting effects of diazotrophs in the rhizosphere. Crit. Rev. Plant Sci. 22:107-149.

Dos Santos, P. C., Fang, Z., Mason, S. W., Setubal, J. C., and Dixon, R. 2012. Distribution of nitrogen fixation and nitrogenase-like sequences amongst microbial genomes. BMC Genomics. 3:13:162.

Elmerich, C., and Newton, W. E. 2007. Associative and endophytic nitrogenfixing bacteria and cyanobacterial associations. Springer. Dordrecht, The Neaderlands.

Elser, J. J. 2011. A world awash with nitrogen. Science 334:1504-1505.
Elser, J. J., Bracken, M. E. S., Cleland, E. E., Gruner, D. S., Harpole, W. S., Hillebrand, H., Ngai, J. T., Seabloom, E. W., Shurin, J. B., and Smith, J. E. 2007. Global analysis of nitrogen and phosphorus limitation of primary production in freshwater, marine, and terrestrial ecosystems. Ecol. Lett. 10:1135-1142.

Erisman, J. W., Sutton, M. A., Galloway, J., Klimont, Z., and Winiwarter, W. 2009. How a century of ammonia synthesis changed the world. Nat. Geosci. 1:636-639.

Fallowski, P. G. 1997. Evolution of the nitrogen cycle and its influence on the biological sequestration of $\mathrm{CO}_{2}$ in the ocean. Nature 387:272-275.

Franche, C., Lindström, C., and Elmerich C. 2009. Nitrogen-fixing bacteria associated with leguminous and non-leguminous. Plant Soil 321:35-59.

Galloway, J. N., Aber, J. D., Erisman, J. W., Seitzinger, S. P., Howarth, R.W., Cowling, E. B., and Cosby. B. J. 2003. The nitrogen cascade. Biosc. 53: 341-356.

Galloway, J. N, Dentener, F. J., Capone, D. G., Boyer, E., W., Howarth, R. W., Seitzinger, S. P. Asner, G. P., Cleveland, C., Green, P., Holland, E. Karl, D., M., Michaels, A., F., Porter. J. H., Townsend, A., and Vörösmarty, C. 2004. Nitrogen cycles: Past, present and future. Biogeochem. 70:153-226.

Galloway, J. N., Townsend, A. R., Erisman, J. W., Bekunda, M., Cai, Z. Freney, J. R., Martinelli, L. A., Seitzinger, P., and Sutton, M. A. 2008. Transformation of the nitrogen cycle: Recent trends, questions, and potential solutions. Science 320:889-892.

Gantar, M., and Elhai, J. 1999. Colonization of wheat para-nodules by the N2-fixing cyanobacterium Nostoc sp. strain 2S9B. New Phytol. 141:373-379.

Graham, P. H., Hungria, M., and Tlusty, B. 2004. Breeding for better nitrogen fixation in grain legumes: Where do the rhizobia fit in? Plant Management Network, Crop Science. doi:10.1094/CM-2004-0301-02-RV. Published online.

Groffman, P. M., Altabet, M. A., Böhlke, J. K., Butterbach-Bahl, K., David, M. B., Firestone, M. K., Giblin, A. E., Kana, T. M., Nielsen, L. P., and Voytek, M. A. 2006. Methods for measuring denitrification: Diverse approaches to a difficult problem. Ecol. Appl. 16:2091-2122.

Gruber, N., and Galloway. J. N. 2008. An earth-system perspective of the global nitrogen cycle. Nature 451:293-296.

Gutierrez, R. A. 2012. Systems biology for enhanced plant nitrogen nutrition. Science 336:1673-1675.

Hatfield, J. L., Boote, K. J., Kimball, B. A., Ziska, L. H., Izaurralde, R. C., Ortr, D. Thomson, A. M., and Wolfe, D. 2011. Climate impacts on agriculture: Implications for crop production. Agron. J. 103:351-370.

Heimann, M., and Reichstein, M. 2008. Terrestrial ecosystem carbon dynamics and climate feedbacks. Nature 451:289-292.

Herridge, D., and Rose, I. 2000. Breeding for enhanced nitrogen fixation in crop legumes. Field Crop Res 65:229-248.

Hocher, V., Alloisio, N., Bogusz, D., and Normand, P. 2011. Early signaling in actinorhizal symbioses. Plant Signal Behav. 6:1377-1379.

Hungria, M., Campo, R. J., and Mendes, I. C. 2005. Reinoculation increasing soybean grain yield in Brazil. Page 315 in: Proceedings of the 14th International Nitrogen Fixation Congress, Springer, Dordrecht, The Netherlands.

Hurek, T., and Reinhold-Hurek, B. 2003. Azoarcus sp. strain BH72 as a model for nitrogen-fixing grass endophytes. J. Biotechnol. 106:169178.

Iniguez, A. L., Domg, Y., and Triplett, E. W. 2004. Nitrogen fixation in wheat provided by Klebsiella pneumoniae 342. Mol. Plant-Microbe Interact. 17:1078-1085.

IPCC 2007. Climate Change 2007: Mitigation. Contribution of Working Group III to the Fourth Assessment Report of the Intergovernmental Panel on Climate Change. B. Metz, O. R. Davidson, P. R. Bosch, R. Dave, L. A. Meyer, eds. Cambridge University Press, Cambridge.

Ivanov, S., Fedorova, E., Limpens, E., De Mita, S., Genre, A., Bonfante P., and Bisseling, T. 2012. Rhizobium-legume symbiosis shares an exocytotic pathway required for arbuscule formation. Proc. Natl. Acad. Sci. U.S.A. 109:8316-8321.

Jensen, E. S., Peoples, M. B., Boddey, R. M., Gresshoff, P. M., Hauggaard-Nielsen, H., Albes, B. J. R., and Morrison, M. J. 2012. Legumes for mitigation of climate change and the provision of feedstock for biofules and biorefineries. A review. Agron. Sustain. Dev. 32:329364.

Keil, D., Meyer, A., Berner, D., Poll, C., Schützenmeister, A., Piepho, H. P., Vlasenko, A., Philippot, L., Schloter, M., Kandeler, E. and Marhan, S. 2011. Influence of land-use intensity on the spatial distribution of $\mathrm{N}$ cycling microorganism in grassland soils. FEMS (Fed. Eur. Microbiol Soc.) Microbiol. Ecol. 77:95-106.

Kennedy I. R., Pereg-Gerk, L., Deaker, R., Wood, C., Gilchrist, K., McFadden, D., and Islam. N. 2000. Critical parameters in facilitating the evolution of $\mathrm{N}_{2}$-fixing symbiosis between diazotrophs and cereals. 
Pages 219-240 in: The Quest for Nitrogen Fixation in Rice, J. K. Ladha and P. M Reddy, eds. International Rice Research Institute, Laguna, Philippines.

Ladha, J. K., and Reddy, P. M. 2000. Steps towards nitrogen fixation in rice. Pages 43-46 in: The quest for Nitrogen fixation in rice, J. K. Ladha and P. M. Reddy, eds. International Rice Research Institute, Laguna, Philippines.

Lindzen, R. S. 2007. Taking greenhouse warming seriously. Energy Environ. 18:937-950.

Maillet, F., Poinsot, V., André, O., Puech-Pagès, V., and Haouy, A. 2011. Fungal lipochitooligosaccharide symbiotic signals in arbuscular mycorrhiza. Nature 469-58-63.

Meeks, J. C. 1998. Symbiosis between nitrogen-fixing cyanobacteria and plants. BioSci. 48:266-276.

Meeks, J. C. 2009. Physiological adaptations in nitrogen-fixing Nostocplant symbiotic associations. Microbiol. Monogr. 8:181-205.

Meeks, J. C., and Elhai, J. 2002. Regulation of cellular differentiation in filamentous cyanobacteria in free-living and plant associated symbiotic growth states. Microbiol. Mol. Biol. Rev. 65:94-121.

Merrick, M., and Dixon, R. 1984. Why don't plants fix nitrogen? Trends Biotech. 2:162-166.

Nicolás, M. F., Hungria, M., and Arias, C. A. A. 2006. Identification of quantitative trait loci controlling nodulation and shoot mass in progenies from two Brazilian soybean cultivars. Field Crops Res. 95:355366.

Oliveira, A. L. M., Canuto, E. L., Urquiaga, S., Reis, V. M., and Baldani, J. I. 2006. Yield of micropropagated sugarcane varieties in different soil types following inoculation with diazotrophic bacteria. Plant Soil 284:23-32.

Ortiz, R., Sayre, K. D., Govaerts, B., Gupta, R., Subbarao, G. V., Ba, T., Hodson, D., Dixon, J. M., Ortiz-Monasterio, J. I., and Reynolds, M. 2008. Climate change: Can wheat beat the heat? Agric. Ecosyst. Environ. 126:46-58.

Peralta, H., Mora, Y., Salazar, E., Encarnación, S., Palacios, R., and Mora, J. 2004. Engineering the nifH promoter region and abolishing poly- $\beta$ hydroxybutyrate accumulation in Rhizobium etli enhance nitrogen fixation in symbiosis with Phaseolus vulgaris. Appl. Environ. Microbiol. 70:3272-3281.

Perrine-Walker, F., Doumas, P., Lucas, M., Vaissayre, V., Beauchemin, N. J., and Band, L. R. 2010. Auxin carriers localization drives auxin accumulation in plant cells infected by Frankia in Casuarina glauca actinorhizal nodules. Plant Physiol. 154:1372-1380.

Philippot, L., and S. Hallin. 2006. Molecular analysis of soil denitrifying bacteria. pp. 146-165. In: Molecular Techniques for Soil, Rizosphere and Plant Microorganisms. J. E. Cooper and J. R. Rao, eds. CABI Publishing, Wallingford, U.K

Phillips, D. A. 1980. Nitrogen efficiency of symbiotic fixation in legumes. Ann. Rev. Plant Physiol. 31:29-49.

Piña-Ochoa E., Hogslund S., Geslin E., Cedhagen T., Revsbech N. P., Nielsen L. P., Schweizer M., Jorissen F., Rysgaard S., and RisgaardPetersen N. 2010. Widespread occurrence of nitrate storage and denitrification among Foraminifera and Gromiida. Proc. Natl. Acad. Sci. U.S.A. 107:1148-1153.

Poole, R. K, and Hill, S. 1997. Respiratory protection of nitrogenase activity in Azotobacter vinelandii-roles of the terminal oxidases. Biosci Rep. 17:303-17.

Postgate, J. 1974. New advances and future potential in biological nitrogen fixation. J. Appl. Bact. 37:185-202.

Prendergast-Miller, M.T., E.M. Baggs, and D.J. Johnson. 2011. Nitrous oxide production by the ectomycorrhizal fungi Paxillus involutus and Tylospora fibrillose. FEMS (Fed. Eur. Microbiol. Soc.) Microbiol. Lett. 316:31-35.

Richardson, D. J. 2011. Redox complexes of the nitrogen cycle. Pages $23-$ 37 in: Nitrogen Cycling in Bacteria: Molecular analysis. J. W. B Moir, ed. Caister Academic Press, Norkfolk, U.K.

Ridge, R. W., Bender, G. L., and Rolfe, B. G. 1992. Nodule-like structures induced on the roots of wheat seedlings by the addition of synthetic auxin 2,4-D, and effects of microorganisms. Austr. J. Plant Phys. 19:481-492.

Ridge, R. W., Ride, K. M., and Rolfe. B. G. 1993. Nodule-like structures induced on the roots of rice seedlings by addition of the synthetic auxin 2,4-dichlorophenoxyacetic acid. Austr. J. Plant Physiol. 20:705717.

Robertson, G. P., and Vitousek, P. M. 2009. Nitrogen in agriculture: Balancing the cost of an essential resource. Annu. Rev. Environ. Res. 34:97-125.

Rubio, L. M., and Ludden, P. W. 2008. Biosynthesis of the iron-molybdenum cofactor of nitrogenase. Ann. Rev. Microbiol. 62:93-111.

Ryle, G. G. A., Powell, C. E., and Gordon, A. J. 1979.The respiratory costs of nitrogen fixation in soybean, cowpea, and white clover. II. Comparisons of the cost of nitrogen fixation and the utilization of combined nitrogen. J. Exp. Bot. 30:145-153.

Salvucci, R. D., Aulicino, M., Hungria, M., and Balatti, P. A. 2012. Nodulation capacity of Argentinean soybean (Glycine max L. Merr) cultivars inoculated with commercial strains of Bradyrhizobium japonicum . Am. J. Plant Sci. 3:130-140.

Schauser, L., Udvardi, M., Tabata, S., and Stougaard, J. 2008. Legume genomics relevant to nitrogen fixation. Pages 211-239 in: Nitrogen-Fixing Leguminous Symbioses, Vol 7. M. J. Dilworth, E. K. James, J. I. Sprent and W. E. Newton, eds. Springer, Berlin.

Sessitsch, A., Howieson, J. G., Perret, X., Antoun, H., and MartínezRomero, E. 2002. Advances in Rhizobium Research. Crit. Rev. Plant Sci. 21:323-378.

Shanmugam, K. T., and Valentine, R. C. 1975. Molecular biology of nitrogen fixation. Science 187:919-924.

Shaw, L. J., W.icol, N. G., Smith, Z., Fear, J., Proser, J. I., and. Baggs, E. M. 2006. Nitrosospira spp. can produce nitrous oxide via a nitrifier denitrification pathway. Environ. Microbiol. 8:214-222.

Shyakila, A., and Kroeze, K. 2011. The global nitrous oxide budget revisited. Greenhouse Gas Meas. Man. 1:17-26.

Silva, M. F., Antonio, C. S., Oliveira, P. J., Xavier, G. R., Rumjanck, N. G., Barros Soares, L. H., and Reis, V. M. 2012. Survival of endophytic bacteria in polymer-based inoculants and efficiency of their application to sugarcane. Plant Soil 356:231-243.

Smil, V. 1999. Nitrogen in crop production: An account of global flows. Global Biogeochem. Cycles 13:647-662.

Soto, M. J., Domínguez-Ferreras, A., Pérez-Mendoza, D., Sanjuán J., and Olivares, J. 2009. Mutualism versus pathogenesis: The give-and-take in plant-bacteria interactions. Cell. Microbiol. 11:381-388.

Spaepen, S. Vanderleyden, J., and Okon, Y. 2009. Plant growth promoting actions of rhizobacteria. Adv. Bot. Res. 51:283-320.

Sutton, M. A., Howard, C. M., Erisman, J. W., Billen, G., Bleeker, A., Grenfelt, P., van Grinsven, H., and Grizeti, B. 2011. The European Nitrogen Assesment: Sources, Effects and Policy Perspectives. Cambridge University Press, Cambridge.

Takaya, N. 2002. Dissimilatory nitrate reduction metabolisms and their control in fungi. J. Biosci. Bioeng. 94:506-510.

Talbi, C., Sánchez, C., Hidalgo-Garcia, A., González, E. M., Arrese-Igor, C., Girard, L., Bedmar, E. J., and Delgado, M. J. 2012. Enhanced expression of Rhizobium etli $\mathrm{cbb}_{3}$ oxidase improves drought tolerance of common bean symbiotic nitrogen fixation. J. Exp. Bot. 63:503543.

Treusch, A. H., Leininger, S., Kletzin, A., Schuster, S.C., Klenk, H. P., and Schleper, C. 2005. Novel genes for nitrate reductase and Amo-related proteins indicate a role of uncultivated mesophilic crenarchaeota in nitrogen cycling. Environ. Microbiol. 7:1985-1995.

Ureta A. C., Imperial, J., Ruiz-Argüeso, T., and Palacios, J. M. 2005. Rhizobium leguminosarum biovar viciae symbiotic hydrogenase activity and processing are limited by the level of nickel in agricultural soils. Appl. Environ. Microbiol. 71:7603-7606.

Ureta, A., and Nordlund, S. 2002. Evidence for conformational protection of nitrogenase against oxygen in Gluconacetobacter diazotrophicus by a putative FeSII protein. J. Bacteriol. 184:5805-5809.

Van Dommelen, A., Croonenborghs, A., Spaepen, S., and Vanderleyden, J. 2009. Wheat growth promotion through inoculation with an ammonium-excreting mutant of Azospirillum brasiliense. Biol. Fertil. Soils 45:449-553.

van Kessel, C., and Hartley, C. 2000. Agricultural management of grain legumes: Has it led to an increase in nitrogen fixation? Field Crops Res. 65:165-181.

van Spanning, R. J., Richardson, D. J., and Ferguson, S. J. 2007. Introduction to the biochemistry and molecular biology of denitrification. Pages 83-93 in: Biology of the Nitrogen Cycle. H. Bothe, S. J. Ferguson, and W. E. Newton, eds. Elsevier. Amsterdam, The Netherlands.

Vitousek, P. M., Aber, J. D., Howarth, R. W., Likens, J. E., Matson, P. A., Schindler, D. W., Schlesinger, W. H., and Tilman, D. G. 1997. Human alteration of the global nitrogen cycle: Sources and consequences. Ecol. Appl. 7:737-750.

Walther, G. R. 2002. Ecological responses to recent climate change. Nature 416:723-741.

Wielbo. J., Marek-Kozaczuk, M., Kubik-Komar, A., and Skorupska, A. 2007. Increased metabolic potential of Rhizobium spp. is associated with bacterial competitiveness. Can. J. Microbiol. 53:957-967.

Yamamoto, H., Kurumiya, S., Ohashi, R., and Fujita, Y. 2011. Functional evaluation of a nitrogenase-like protochlorophyllide reductase encoded by the chloroplast DNA of Physcomitrella patens in the cyanobacterium Leptolyngbya boryana. Plant Cell Physiol. 52:1983-93.

Yanni, Y. G., and Dazzo, F. B. 2010. Enhancement of rice production using 
endophytic strains of Rhizobium leguminosarum bv. trifolii in extensive field inoculation trials within the Egypt Nile delta. Plant Soil 336:129142.

Zamioudis, C., and Pieterse, C. M. J. 2012. Modulation of host immunity by beneficial microbes. Mol. Plant Microbe Interact. 25:139-50.

Zeman, A. M., Tchan, Y. T., Elmerich, C., and Kennedy, L. R. 1992. Nitrogenase activity in wheat seedlings bearing para-nodules induced by $2,4-$ dichlorophenoxyacetic acid (2,4-D) and inoculated with Azospirillum. Res. Microbiol. 143:847-855.
Zumft, W. G. 1997. Cell biology and molecular basis of denitrification. Microbiol. Mol. Biol. Rev. 61:533-616.

\section{AUTHOR-RECOMMENDED INTERNET RESOURCES}

N2Africa program: www.n2africa.org

John Innes Center News website: news.jic.ac.uk/2012/07/cereals-selffertilise 